\title{
Manufacturing Process Development for Belzutifan, Part 6: Ensuring Scalability for a Deoxyfluorination Reaction
}

\section{Supporting Information}

\author{
Michael Pirnot, ${ }^{* \ddagger}$ Kevin Stone, ${ }^{* \ddagger}$ Timothy J. Wright, ${ }^{\ddagger}$ David J. Lamberto, ${ }^{\ddagger}$ Jochen Schoell, ${ }^{\perp}$ Yu- \\ hong Lam, ${ }^{ \pm}$Kerstin Zawatzky, Xiao Wang, ${ }^{\ddagger}$ Stephen M. Dalby, ${ }^{\ddagger}$ Adam J. Fine, ${ }^{\ddagger}$ Jonathan P. \\ McMullen ${ }^{\ddagger}$ \\ ${ }^{\ddagger}$ Department of Process Research and Development, Merck Research Laboratories, 126 E. Lincoln Avenue, Rahway, \\ NJ 07065 \\ ${ }^{ \pm}$Department of Computational and Structural Chemistry, Merck Research Laboratories, 126 E. Lincoln Avenue, \\ Rahway, NJ 07065 \\ ${ }^{\perp}$ Department of Process Research and Development, MSD Werthenstein BioPharma, Industrie Nord 1, CH-6105 \\ Schachen, Switzerland

\section{michael.pirnot@merck.com \& kevin.stone@merck.com}

Table of Contents

1. General experimental details

2. UPLC Method Information for Deoxyfluorination Reaction

3. General Procedures for Deoxyfluorination Studies

4. Additional Water Doping Studies

5. Additional Information for Mixing Studies

6. Analytical Information for Pilot Plant Campaign

7. DFT Computational Details

8. Characterization Data for MK-6482

9. References

\section{General experimental details}

With the exception of reactions run in Mettler-Toledo vessels, cooling and stirring of reaction mixtures was performed using a closed-loop chiller and overhead stirring with a thermocouple to confirm the internal temperature of the reaction mixture. Mettler-Toledo reaction vessels employed include $100 \mathrm{~mL}$ EasyMAX vessels (glass) in an EasyMAX 102 system with iControl software for data logging and control. The vessels are equipped with a sleeved thermocouple and overhead agitation with a pitched blade. High resolution mass spectrometry data were collected on a Waters Xevo G2 Qtof. KF measurements were performed on a Metrohm 756 KF Coulometer. 
Reagents were purchased in reagent grade from commercial suppliers and used without further purification. Anhydrous solvents were obtained from Sigma-Aldrich as part of their SureSeal ${ }^{\mathrm{TM}}$ bottles product line. NMR experiments utilized deuterated solvents purchased from Sigma Aldrich or Cambridge Isotope Laboratories. UPLC eluent mixtures were made with UPLC/HPLC grade $\mathrm{MeCN}, \mathrm{MeOH}, \mathrm{H}_{2} \mathrm{O}$ and $99.99 \% \mathrm{H}_{3} \mathrm{PO}_{4}$. DBU was weighed in the glovebox; it was found that repeated use of DBU under ambient conditions outside of the glovebox caused a slight deterioration in its effectiveness.

Proton nuclear magnetic resonance $\left({ }^{1} \mathrm{H}\right.$ NMR) spectra, carbon nuclear magnetic resonance $\left({ }^{13} \mathrm{C}\right.$ $\mathrm{NMR}$ ) spectra, and proton decoupled fluorine nuclear magnetic resonance $\left({ }^{19} \mathrm{~F} N \mathrm{NM}\right)$ spectra were recorded at $25^{\circ} \mathrm{C}$ unless stated otherwise on a Bruker DRX-500 spectrometer or a Bruker Neo $600 \mathrm{MHz}$ spectrometer equipped with an iProbe TBO. ${ }^{1} \mathrm{H}$ and ${ }^{13} \mathrm{C}$ chemical shifts were referenced to the NMR solvent according to values reported in the literature, ${ }^{1}$ and ${ }^{19} \mathrm{~F}$ chemical shifts were calibrated by indirect referencing. For samples in acetonitrile- $d_{3}$, the solvent signals were referenced to $1.94 \mathrm{ppm}$ in ${ }^{1} \mathrm{H}$, and $118.26 \mathrm{ppm}$ in ${ }^{13} \mathrm{C}$. Data are presented as follows: chemical shift, integration, multiplicity ( $b r=$ broad, $s=$ singlet, $d=$ doublet, $t=$ triplet, $q=$ quartet, quint = quintet, $m=$ multiplet, $d t=$ doublet of triplets), coupling constants $(J)$ in $\mathrm{Hertz}(\mathrm{Hz})$. Analysis of reaction mixtures and quantification of starting material and product was done using either quantitative ${ }^{1} \mathrm{H}$ NMR analysis $\left({ }^{1} \mathrm{H}\right.$ qNMR, $\mathrm{d} 1=60$ seconds, number of scans $\left.=8\right)$ or $\mathrm{HPLC}$ or UPLC methods (see HPLC method information).

\section{UPLC Method Information for Deoxyfluorination Reaction}

\begin{tabular}{|c|c|}
\hline Column: & $\begin{array}{l}\text { ACE C18-PFP, Ultra-Inert HPLC Column, } 100 \text { mm x } 3.0 \\
\mathrm{~mm} \text {, 3um (P/N: ACE-1110-1003) }\end{array}$ \\
\hline Column Temperature: & $50^{\circ} \mathrm{C}$ \\
\hline Autosampler Temperature: & Ambient \\
\hline Flow rate: & $0.7 \mathrm{~mL} / \mathrm{min}$ \\
\hline Injection Volume: & $3 \mathrm{~mL}$ \\
\hline Detector: & UV at $233 \mathrm{~nm}$ \\
\hline Band Width (DAD): & $4 \mathrm{~nm}$ \\
\hline Run Time & $50 \mathrm{~min}$ \\
\hline Needle Wash: & Acetonitrile \\
\hline \multirow[t]{2}{*}{ Mobile Phase: } & A: $\mathrm{H}_{2} \mathrm{O} / \mathrm{MeOH} 80: 20$ (0.1\% phosphoric acid) \\
\hline & B: Methanol/Acetonitrile 90:10 \\
\hline \multirow[t]{6}{*}{ Mobile Phase Program: } & Time (min) $\quad \% B$ \\
\hline & 0.0 \\
\hline & 12.0 \\
\hline & 36.00 \\
\hline & 40.00 \\
\hline & 42.00 \\
\hline
\end{tabular}




$\begin{array}{ll}47.00 & 95 \\ 47.10 & 15 \\ 50.00 & 15\end{array}$

Approximate Relative Retention Times of the specified impurities

\begin{tabular}{|l|l|}
\hline Compound & $\underline{\text { RRT }}$ \\
\hline Fluoro-diol $\mathbf{3}$ & 0.50 \\
\hline SM epimer $\mathbf{9}$ & 0.55 \\
\hline Belzutifan (5) & 1.00 \\
\hline DME adduct 10 & 1.37 \\
\hline API epimer 11 & 1.49 \\
\hline $\begin{array}{l}\text { Tri-fluoro } \\
\text { impurity 12 }\end{array}$ & 1.77 \\
\hline SM dimer 14 & 1.98 \\
\hline API-SM dimer 13 & 2.27 \\
\hline $\begin{array}{l}\text { DME adduct-SM } \\
\text { dimer } \mathbf{1 5}\end{array}$ & $\mathbf{2 . 4 3}$ \\
\hline
\end{tabular}

The retention time for belzutifan is approximately 16 minutes.

Figure S1 Representative HPLC Chromatograms - Overlay of blank and resolution solution

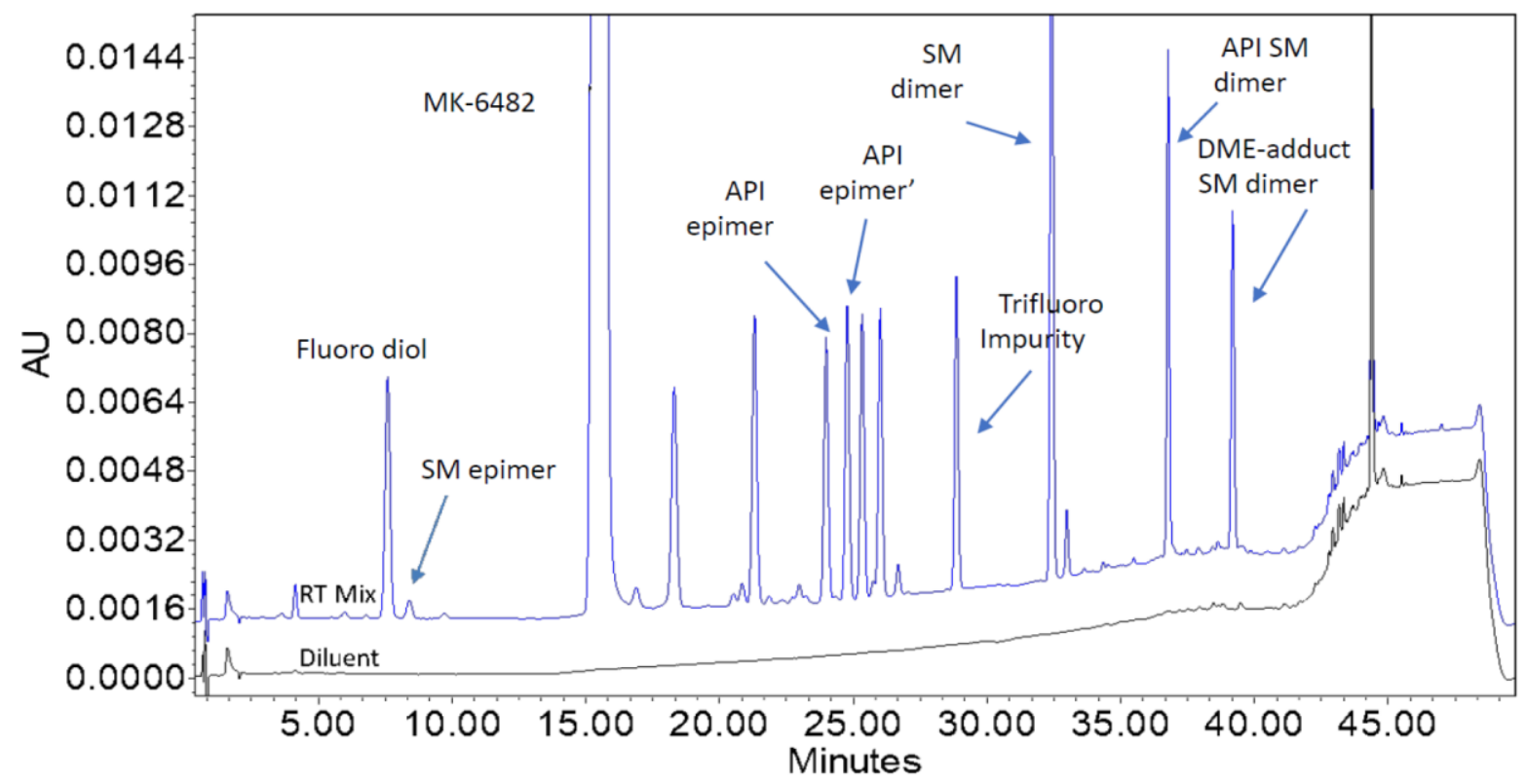


UPLC Sample Preparation and Analysis: $15 \mu \mathrm{L}$ of reaction mixture diluted in $1.5 \mathrm{~mL}$ 90:10 MeCN:water. The UPLC peak associated with DBU and artifacts on the UPLC assay are not integrated for LCAP determination of the reaction mixture.

\section{General Procedures for Deoxyfluorination Studies}

\section{Procedure for Stoichiometry Studies}

3-fluoro-5-(((1S,2R,3S)-2-fluoro-1,3-dihydroxy-7-(methylsulfonyl)-2,3-dihydro-1H-inden-4yl)oxy)benzonitrile (fluoro diol 3, $10.0 \mathrm{~g}, 24.91 \mathrm{mmol}, 95.0 \mathrm{wt} \%$ ) and 5 vol anhydrous DME (50 $\mathrm{mL}$ ) were charged to a $250 \mathrm{~mL}$ three-neck flask equipped with a distillation head with $100 \mathrm{~mL}$ round-bottom flask, thermocouple and overhead stirrer. Closed loop chiller was connected to $250 \mathrm{~mL}$ three-neck flask. KF was tested for this solution: approximately 4700 to $4900 \mathrm{ppm}$. Internal temperature of vessel was heated to $55^{\circ} \mathrm{C}$ and azeotropic distillation was performed by reducing pressure to 170 to 250 torr and reducing volume of mixture to $3.5 \mathrm{~V}(35 \mathrm{~mL})$. After concentration was complete, 2.0 vol anhydrous DME $(20 \mathrm{~mL})$ was charged to the vessel. This was repeated a total of 2 to 3 times to use 6.0 to 8.0 vol DME for the azeotropic distillation. KF was checked of the reaction mixture and must be below $<500 \mathrm{ppm}$ to continue. Additional $3.0 \mathrm{vol}$ DME $(30 \mathrm{~mL})$ was added to the reaction mixture to a reach total volume of $8.5 \mathrm{~V}(85 \mathrm{~mL})$ for the fluoro diol/DME solution. Reaction mixture was cooled to $-20{ }^{\circ} \mathrm{C}$ (internal temperature) and a specified amount of perfluoro-1-butanesulfonyl fluoride (PBSF) was charged to the vessel via syringe. A solution of a specified amount of 1,8-Diazabicyclo[5.4.0] undec-7-ene (DBU) and 2.0 vol DME $(20.0 \mathrm{~mL})$ was charged above surface via syringe pump to the cooled solution of fluoro diol, PBSF, and DME. The DBU/DME solution was charged over the course of $1 \mathrm{~h}$ above surface. After

the DBU/DME solution was charged to the reaction mixture, the reaction mixture was stirred at $-20{ }^{\circ} \mathrm{C}$ for $1 \mathrm{~h}$. An aliquot was subsequently taken and diluted 200x in 90:10 MeCN:water and analyzed via UPLC assay for analysis.

\section{Procedures for Investigation of Other Orders of Addition Studies}

\section{DBU Addition Before PBSF Addition}

3-fluoro-5-(((1S,2R,3S)-2-fluoro-1,3-dihydroxy-7-(methylsulfonyl)-2,3-dihydro-1H-inden-4yl)oxy)benzonitrile (anhydrous fluoro diol 3, $10.0 \mathrm{~g}, 25.9 \mathrm{mmol}, 98.8 \mathrm{wt} \%$ ) and 7 vol anhydrous DME (70 mL) were charged to a $250 \mathrm{~mL}$ three-neck flask equipped with a condenser with nitrogen inlet, thermocouple and overhead stirrer. Closed loop chiller was connected to $250 \mathrm{~mL}$ threeneck flask. KF was tested for this solution and $<500 \mathrm{ppm}$ was observed. Reaction mixture was cooled to $-20{ }^{\circ} \mathrm{C}$ (internal temperature) and a solution of DBU $(4.46 \mathrm{~mL}, 4.54 \mathrm{~g}, 29.8 \mathrm{mmol}, 1.15$ equiv) and 2.0 vol DME (20 mL) was charged above surface via syringe pump to the cooled solution of fluoro diol and DME. The DBU/DME solution was charged over the course of $30 \mathrm{~min}$ above surface. After the DBU/DME solution was charged to the reaction mixture, PBSF $(5.36 \mathrm{~mL}$, 
$9.00 \mathrm{~g}, 29.8 \mathrm{mmol}, 1.15$ equiv) was charged above surface via syringe pump to the cooled solution of fluoro diol, DBU, and DME. PBSF was charged over the course of $30 \mathrm{~min}$ above surface. The reaction mixture was stirred at $-20^{\circ} \mathrm{C}$ for $30 \mathrm{~min}$. An aliquot was subsequently taken and diluted 200x in 90:10 MeCN:water and analyzed via UPLC assay for analysis.

\section{Simultaneous Addition of PBSF and DBU}

3-fluoro-5-(((1S,2R,3S)-2-fluoro-1,3-dihydroxy-7-(methylsulfonyl)-2,3-dihydro-1H-inden-4yl)oxy)benzonitrile (anhydrous fluoro diol 3, $10.0 \mathrm{~g}, 25.9 \mathrm{mmol}, 98.8 \mathrm{wt} \%$ ) and 7 vol anhydrous DME $(70 \mathrm{~mL}$ ) were charged to a $250 \mathrm{~mL}$ three-neck flask equipped with a condenser with nitrogen inlet, thermocouple and overhead stirrer. Closed loop chiller was connected to $250 \mathrm{~mL}$ threeneck flask. KF was tested for this solution and $<500 \mathrm{ppm}$ was observed. Reaction mixture was cooled to $-20{ }^{\circ} \mathrm{C}$ (internal temperature). A solution of DBU $(4.46 \mathrm{~mL}, 4.54 \mathrm{~g}, 29.8 \mathrm{mmol}, 1.15$ equiv) and 2.0 vol DME $(20 \mathrm{~mL})$ was charged above surface via syringe pump to the cooled solution of fluoro diol and DME over $1 \mathrm{~h}$. Simultaneously, PBSF (5.36 mL, $9.00 \mathrm{~g}, 29.8 \mathrm{mmol}, 1.15$ equiv) was charged above surface via syringe pump to the reaction mixture over $1 \mathrm{~h}$. The reaction mixture was stirred at $-20^{\circ} \mathrm{C}$ for $1 \mathrm{~h}$. An aliquot was subsequently taken and diluted 200x in 90:10 MeCN:water and analyzed via UPLC assay for analysis.

\section{Procedure for Temperature Studies}

3-fluoro-5-(((1S,2R,3S)-2-fluoro-1,3-dihydroxy-7-(methylsulfonyl)-2,3-dihydro-1H-inden-4yl)oxy)benzonitrile (fluoro diol 3 hydrate, $10.0 \mathrm{~g}, 25.9 \mathrm{mmol}, 98.8 \mathrm{wt} \%$ ) and 8 vol anhydrous DME $(80 \mathrm{~mL})$ were charged to a $100 \mathrm{~mL}$ Easy-Max reactor equipped with a thermocouple, nitrogen inlet, and overhead stirrer. KF was tested for this solution and $<500 \mathrm{ppm}$ was observed. Reaction mixture was cooled to specified temperature (internal temperature) and PBSF $(5.47 \mathrm{~mL}, 9.18 \mathrm{~g}$, $29.8 \mathrm{mmol}, 1.15$ equiv) was charged to the vessel via syringe. A solution of DBU $(4.55 \mathrm{~mL}, 4.63 \mathrm{~g}$, $29.8 \mathrm{mmol}, 1.15$ equiv) and 2.0 vol DME (20.0 mL) was charged above surface via syringe pump to the cooled solution of fluoro diol, PBSF, and DME. The DBU/DME solution was charged over the course of $1 \mathrm{~h}$ above surface. After the DBU/DME solution was charged to the reaction mixture, the reaction mixture was stirred at the specified temperature for $1 \mathrm{~h}$. An aliquot was subsequently taken and diluted 200x in 90:10 MeCN:water and analyzed via UPLC assay for analysis.

\section{Procedure Water Doping Studies}

3-fluoro-5-(((1S,2R,3S)-2-fluoro-1,3-dihydroxy-7-(methylsulfonyl)-2,3-dihydro-1H-inden-4yl)oxy)benzonitrile (fluoro diol 3 hydrate, $5.0 \mathrm{~g}, 12.85 \mathrm{mmol}, 98.0 \mathrm{wt} \%$ ) and 8 vol anhydrous DME $(40 \mathrm{~mL})$ were charged to a $100 \mathrm{~mL}$ Easy-Max reactor equipped with a thermocouple, nitrogen 
inlet, and overhead stirrer. KF was tested for this solution and water was added to reaction mixture, stirred, and KF measured again to determine KF level before PBSF addition. Reaction mixture was cooled to $-20^{\circ} \mathrm{C}$ (internal temperature) and a specified amount of PBSF was charged to the vessel via syringe. A solution of a specified amount of DBU and 2.0 vol DME $(10 \mathrm{~mL})$ was charged above surface via syringe pump to the cooled solution of fluoro diol, PBSF, and DME. The DBU/DME solution was charged over the course of $1 \mathrm{~h}$ above surface. After the DBU/DME solution was charged to the reaction mixture, the reaction mixture was stirred at the specified temperature for $1 \mathrm{~h}$. An aliquot was subsequently taken and diluted 200x in 90:10 MeCN:water and analyzed via UPLC assay for analysis. If a kicker charge is used, a specified amount of PBSF is added to the reaction mixture via syringe and the mixture is stirred for $10 \mathrm{~min}$. Subsequently, a specified amount of DBU and DME is charged via syringe over the course of $5 \mathrm{~min}$. The reaction mixture is stirred for $30 \mathrm{~min}$, and an aliquot was subsequently taken and diluted 200x in 90:10 MeCN:water and analyzed via UPLC assay for analysis.

\section{Additional Water Doping Studies}

Several reactions were run with differing levels of water using 1.10 equiv DBU, 1.15 equiv PBSF. If IPC was not met (<4 LCAP fluoro-diol 3), a kicker charge of both PBSF and DBU was added until conversion of $<4$ LCAP fluoro-diol 3 remained in the reaction mixture. From this data, a linear trend was observed with the charge modifier as a function of KF prior to DBU addition. The charge modifier $(\mathrm{Y})$ used for the deoxyfluorination reaction is additional equivalents of PBSF and DBU used ( 1.15 equiv PBSF $+Y$ ), (1.10 equiv DBU $+Y$ ). For example, 1.35 equiv PBSF and 1.30 equiv $\mathrm{DBU}$ would be a charge modifier $Y=0.20$. For all four cases, the purity profile for the reaction mixtures was consistent.

\section{Determination of Charge Modifier}
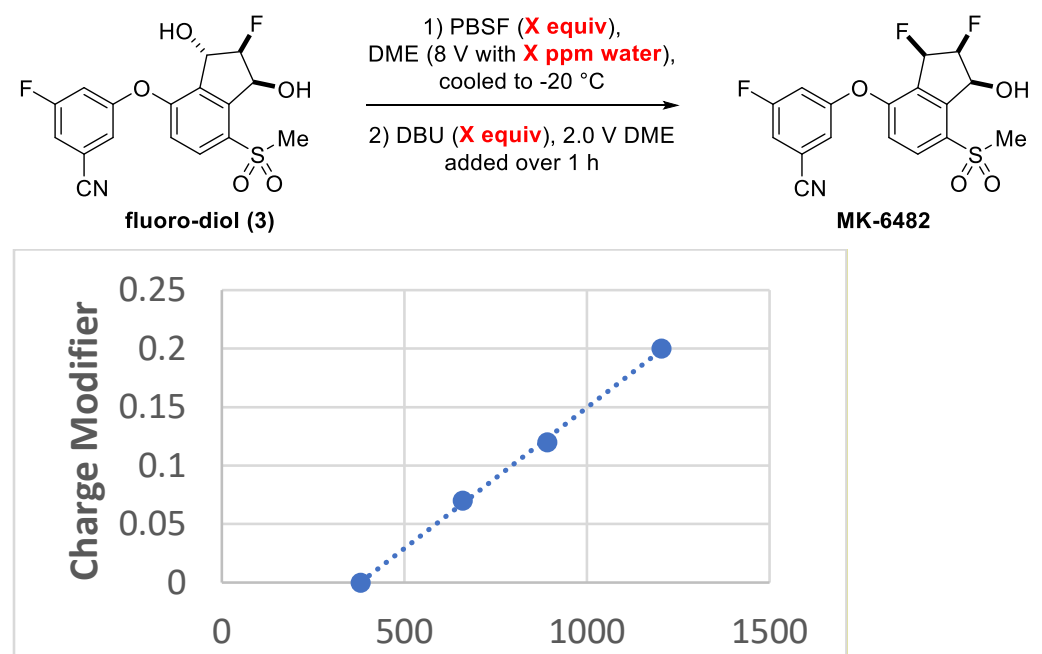

KF of Reaction Before DBU Addition 
Charge Modifier for Differing Levels of Water in Deoxyfluorination Reaction ${ }^{a}$

\begin{tabular}{|c|c|c|c|c|}
\hline Entry & $\mathbf{1}$ & $\mathbf{2}$ & $\mathbf{3}$ & $\mathbf{4}$ \\
\hline $\begin{array}{c}\text { KF of } \\
\text { reaction }\end{array}$ & 380 & 665 & 891 & 1204 \\
\hline $\begin{array}{c}\text { Equiv, water, } \\
\text { in reaction }\end{array}$ & 0.06 & 0.10 & 0.13 & 0.18 \\
\hline $\begin{array}{c}\text { Charge } \\
\text { Modifier }\end{array}$ & 0.0 & 0.07 & 0.12 & 0.20 \\
\hline DBU equiv & 1.10 & 1.17 & 1.22 & 1.30 \\
\hline $\begin{array}{c}\text { PBSF equiv } \\
\text { Fluoro-diol 3 }\end{array}$ & 1.15 & 1.22 & 1.27 & 1.35 \\
\hline SM-epimer 9 & 0.3 & 0.7 & 0.9 & 0.6 \\
\hline MK6482 (5) & 84.5 & 85.0 & 85.1 & 86.3 \\
\hline $\begin{array}{c}\text { DME-adduct } \\
\mathbf{1 0}\end{array}$ & 5.0 & 5.0 & 5.0 & 4.5 \\
\hline $\begin{array}{c}\text { API epimer } \\
\mathbf{1 1}\end{array}$ & 1.0 & 1.1 & 1.0 & 1.0 \\
\hline $\begin{array}{c}\text { Tri-fluoro } \\
\text { Impurity 12 }\end{array}$ & 0.1 & 0.1 & 0.2 & 0.2 \\
\hline SM-dimer 14 & 1.0 & 1.0 & 1.1 & 0.9 \\
\hline
\end{tabular}

a Purity profile of reaction mixtures determined by UPLC analysis (LC area\%, $233 \mathrm{~nm}$ ); ${ }^{b}$ Water equivalents estimated from calculating grams of water in 8 vol DME with KF measurement observed for each reaction.

\section{Additional Information for Mixing Studies}

Detailed Design of Mixing Experiments for Table 6

\begin{tabular}{|c|c|c|c|c|c|c|}
\hline \multirow{2}{*}{ Parameter } & \multicolumn{3}{|c|}{ Geometry 1 } & \multicolumn{3}{c|}{ Geometry 2 } \\
\cline { 2 - 7 } & Exp. 1-1 & Exp. 1-2 & Exp. 1-3 & Exp. 2-1 & Exp. 2-2 & Exp. 2-3 \\
\hline $\begin{array}{c}\text { Agitation } \\
\text { (RPM) }\end{array}$ & 475 & 725 & 425 & 500 & 575 & 425 \\
\hline $\begin{array}{c}\text { Impeller } \\
\text { Location } \\
\left(\mathbf{Z} / \mathbf{H}_{\mathrm{L})}\right.\end{array}$ & 0.18 & 0.18 & 0.18 & 0.30 & 0.30 & 0.30 \\
\hline $\begin{array}{c}\text { Impeller } \\
\text { Diameter } \\
\text { (D/T) }\end{array}$ & 0.45 & 0.45 & 0.45 & 0.45 & 0.45 & 0.45 \\
\hline $\begin{array}{c}\text { Feed } \\
\text { Location } \\
\left(\mathbf{Z} / \mathbf{H}_{\mathrm{L})}\right.\end{array}$ & 0.85 & 0.33 & 0.70 & 0.85 & 0.53 & 0.70 \\
\hline
\end{tabular}




\begin{tabular}{|c|c|c|c|c|c|c|}
\hline $\begin{array}{c}\text { Feed } \\
\text { Radial } \\
\text { Position } \\
\text { (D/T) } \\
\end{array}$ & 0.75 & 0.45 & 0.75 & 0.75 & 0.45 & 0.75 \\
\hline $\begin{array}{c}\text { Feed } \\
\text { Diameter } \\
(\mathrm{mm})\end{array}$ & 0.60 & 0.60 & 0.41 & 0.60 & 0.60 & 0.41 \\
\hline $\begin{array}{c}\text { Feed Time } \\
(\min )\end{array}$ & 60 & 60 & 30 & 60 & 60 & 30 \\
\hline $\begin{array}{c}\text { Estimated } \\
\epsilon_{\text {average }} \\
(\mathrm{W} / \mathrm{kg})\end{array}$ & 0.15 & 0.54 & 0.11 & 0.15 & 0.22 & 0.09 \\
\hline $\begin{array}{c}\text { Estimated } \\
\epsilon_{\text {local }} \\
(\mathrm{W} / \mathrm{kg})\end{array}$ & 0.04 & 1.13 & 1.82 & 0.04 & 0.49 & 1.82 \\
\hline $\begin{array}{l}\text { Estimated } \\
t_{\text {micro }}(\mathrm{ms})\end{array}$ & 76.6 & 14.7 & 11.6 & 76.8 & 22.4 & 11.6 \\
\hline $\begin{array}{l}\text { Estimated } \\
t_{\text {meso }}(\mathrm{ms})\end{array}$ & 31.8 & 7.3 & 11.8 & 31.3 & 10.4 & 11.8 \\
\hline
\end{tabular}

\section{Calculation of Power for Typical Equipment in Figure 7}

\begin{tabular}{|c|c|c|}
\hline Scale & $\begin{array}{c}\text { Impeller } \\
\text { Diameter }(\mathbf{m})\end{array}$ & $\begin{array}{c}\text { Solution Mass } \\
(\mathbf{k g})\end{array}$ \\
\hline $10 \mathrm{~g}$ & 0.025 & 0.091 \\
\hline $100 \mathrm{~g}$ & 0.045 & 0.91 \\
\hline $30 \mathrm{~kg}$ & 0.30 & 274 \\
\hline $500 \mathrm{~kg}$ & 0.80 & 4572 \\
\hline
\end{tabular}

Constants for all cases: Impeller power number of 1.0, solution density of $1040 \mathrm{~kg} / \mathrm{m} 3$

$$
P=P o * \rho_{L} * N^{3} D^{5}
$$

\begin{tabular}{|c|c|c|c|c|}
\hline \multirow{2}{*}{ Agitator Speed (RPM) } & \multicolumn{5}{|c|}{ Power (W/ kg) for Each Scale } \\
\cline { 2 - 5 } & $\mathbf{1 0} \mathbf{~}$ & $\mathbf{1 0 0} \mathbf{~ g}$ & $\mathbf{3 0} \mathbf{~ g}$ & $\mathbf{5 0 0} \mathbf{~ g}$ \\
\hline 50 & 0.00 & 0.00 & 0.01 & 0.04 \\
\hline 100 & 0.00 & 0.00 & 0.04 & 0.35 \\
\hline 150 & 0.00 & 0.00 & 0.14 & 1.16 \\
\hline 200 & 0.00 & 0.01 & 0.34 & - \\
\hline 250 & 0.01 & 0.02 & 0.67 & - \\
\hline 300 & 0.01 & 0.03 & 1.15 & - \\
\hline 350 & 0.02 & 0.04 & - & - \\
\hline 400 & 0.03 & 0.06 & - & - \\
\hline 450 & 0.05 & 0.09 & - & - \\
\hline
\end{tabular}




\begin{tabular}{|c|l|l|l|l|}
\hline 500 & 0.06 & 0.12 & - & - \\
\hline 550 & 0.09 & 0.16 & - & - \\
\hline 600 & 0.11 & 0.21 & - & - \\
\hline 650 & 0.14 & 0.27 & - & - \\
\hline 700 & 0.18 & 0.33 & - & - \\
\hline 750 & 0.22 & 0.41 & - & - \\
\hline 800 & 0.26 & 0.50 & - & - \\
\hline 850 & 0.32 & 0.60 & - & - \\
\hline 900 & 0.37 & 0.71 & - & - \\
\hline 950 & 0.44 & 0.83 & - & - \\
\hline 1000 & 0.51 & 0.97 & - & - \\
\hline
\end{tabular}

6. Analytical Information for Pilot Plant Campaign

Analytical Data for Isolated Crude API Solids from Pilot Plant Campaign

\begin{tabular}{|c|c|c|c|}
\hline \multicolumn{3}{|c|}{ Crude MK-6482 API SSO PPB2 } & \\
\hline Name & RT & $\%$ Area & wt\% \\
\hline SM-epimer 9 & 8.636 & 0.07 & \\
\hline MK-6482 (5) & 15.795 & 97.83 & 95.94 \\
\hline DME-adduct 10 & 21.786 & 1.05 & \\
\hline API epimer 11 & 23.695 & 0.06 & \\
\hline $\begin{array}{c}\text { Tri-fluoro } \\
\text { impurity 12 }\end{array}$ & 28.469 & 0.15 & \\
\hline SM dimer 14 & 31.802 & 0.11 & \\
\hline API SM dimer 13 & 36.395 & 0.17 & \\
\hline DME-adduct SM & & & \\
dimer 15 & 39.059 & 0.15 & \\
\hline
\end{tabular}

Analytical Data for Isolated Pure API Solids from Pilot Plant Campaign

\begin{tabular}{|c|c|c|}
\hline Name & \% Area & wt\% \\
\hline MK-6482 (5) & 99.92 & 99.8 \\
\hline $\begin{array}{c}\text { DME-adduct } \\
\mathbf{1 0}\end{array}$ & 0.08 & \\
\hline
\end{tabular}




\section{DFT Computational Details}

The quantum chemical calculations were performed using the Gaussian 16 program. ${ }^{2}$ Geometry optimizations and frequency calculations were performed at the M06-2X3/6-31+G(d,p) level of theory. An "ultrafine" integration grid and a two-electron integral accuracy of $10^{-14}$ (int $=($ Acc2E $=14$, ultrafine $)$ ) were used. The stationary points were characterized as minima by the presence of only positive eigenvalues of the Hessian. The Gibbs energies were calculated for $298.15 \mathrm{~K}$ and $1 \mathrm{~atm}$ using the quasi-harmonic approximation proposed by Cramer and Truhlar, ${ }^{4}$ in which all of the real vibrational frequencies lower than $100 \mathrm{~cm}^{-1}$ were set to $100 \mathrm{~cm}^{-1}$ before the thermal corrections were computed with the usual harmonic oscillator model.

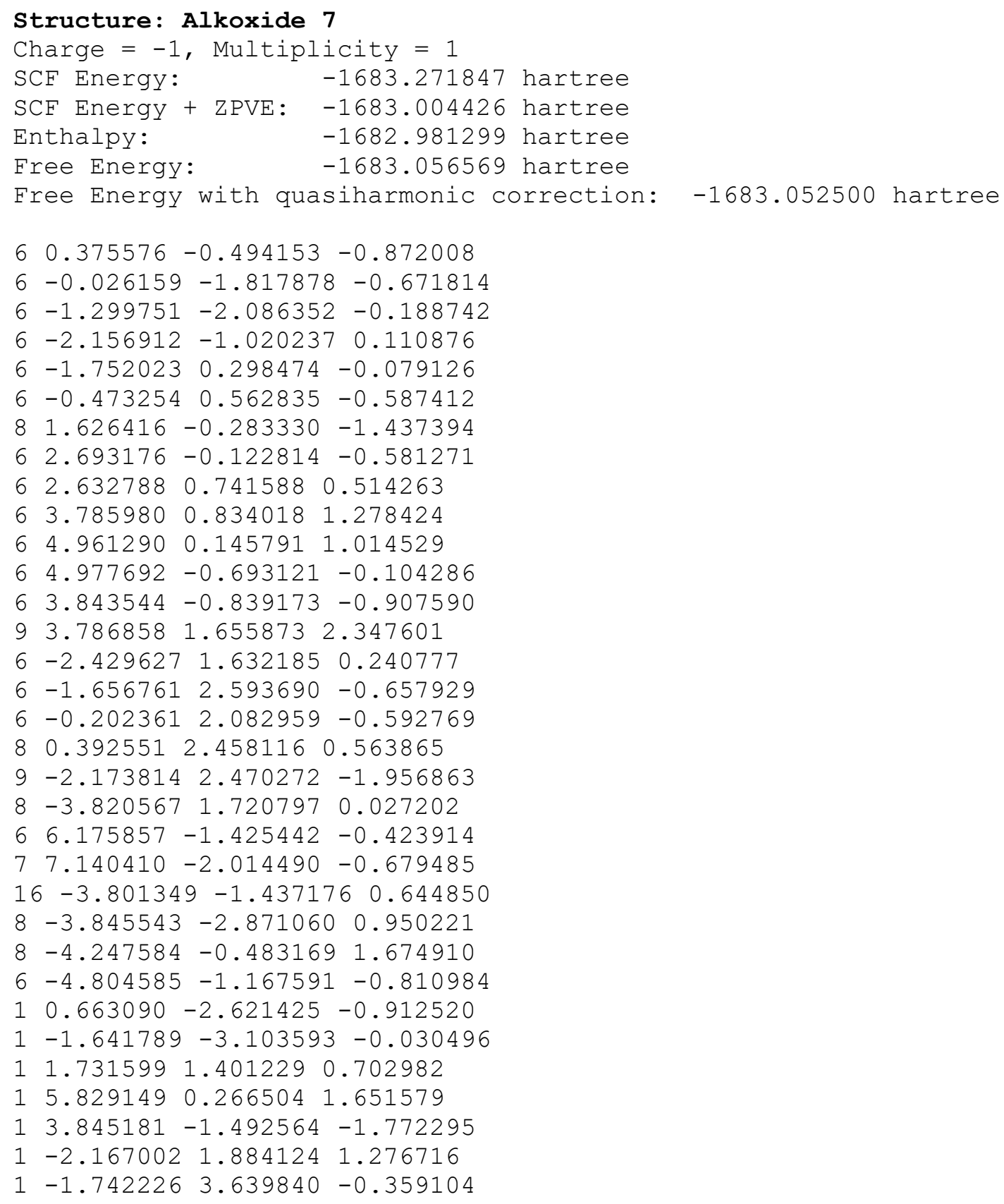


$\begin{array}{lllll}1 & 0.321509 & 2.376611 & -1.529470\end{array}$

$1-4.246793 \quad 1.305775 \quad 0.790996$

$1-5.831163-1.394442-0.515940$

$1-4.689520-0.125053-1.113432$

$\begin{array}{lllll}1 & -4.459723 & -1.855561 & -1.583442\end{array}$

\section{Structure: Alkoxide 7 '}

Charge $=-1$, Multiplicity $=1$

SCF Energy: $\quad-1683.265676$ hartree

SCF Energy + ZPVE: -1682.998134 hartree

Enthalpy: $\quad-1682.974637$ hartree

Free Energy: $\quad-1683.050395$ hartree

Free Energy with quasiharmonic correction: -1683.046509 hartree

$6-0.113514-1.215951-0.783518$

$\begin{array}{lllll}6 & 0.714005 & -2.335775 & -0.681152\end{array}$

$62.067545-2.163699-0.407482$

$6 \quad 2.582995-0.875392-0.260577$

$\begin{array}{llll}6 & 1.766975 & 0.245589 & -0.382927\end{array}$

$60.4003590 .064514-0.639086$

$8-1.448817-1.447166-1.083054$

$6-2.409645-0.941555-0.272156$

$6-2.170466-0.5363851 .042722$

$6-3.251016-0.0868651 .788404$

$6-4.544986-0.0239091 .304396$

$\begin{array}{lllll}6 & -4.749884 & -0.444322 & -0.016714\end{array}$

$\begin{array}{llll}6 & -3.699402 & -0.899781 & -0.809013\end{array}$

$\begin{array}{lllll}9 & -3.028472 & 0.299328 & 3.057536\end{array}$

$\begin{array}{llll}6 & 2.044317 & 1.742603 & -0.077118\end{array}$

$\begin{array}{lllll}6 & 0.884027 & 2.332177 & -0.931121\end{array}$

$\begin{array}{lllll}6 & -0.294122 & 1.401287 & -0.666022\end{array}$

$\begin{array}{llll}8 & -1.333245 & 1.440658 & -1.633229\end{array}$

$\begin{array}{lllll}9 & 0.552703 & 3.639835 & -0.600192\end{array}$

$\begin{array}{lllll}8 & 1.910704 & 1.945658 & 1.244393\end{array}$

$6-6.082411-0.401333-0.565449$

$\begin{array}{lllll}7 & -7.155974 & -0.368609 & -0.998254\end{array}$

$\begin{array}{lllll}16 & 4.315635 & -0.688953 & 0.132923\end{array}$

$\begin{array}{lllll}8 & 4.868350 & -2.043957 & 0.301158\end{array}$

$\begin{array}{llllll}8 & 4.946651 & 0.206707 & -0.842432\end{array}$

$\begin{array}{lllll}6 & 4.283256 & 0.129111 & 1.715892\end{array}$

$\begin{array}{lllll}1 & 0.280566 & -3.322264 & -0.805756\end{array}$

$12.734133-3.013844-0.300903$

$\begin{array}{lllll}1 & -1.177171 & -0.552010 & 1.479813\end{array}$

$\begin{array}{llll}1 & -5.354230 & 0.336839 & 1.926383\end{array}$

$\begin{array}{lllll}1 & -3.854997 & -1.207814 & -1.835594\end{array}$

$\begin{array}{lllll}1 & 3.015203 & 2.055940 & -0.518183\end{array}$

$\begin{array}{lllll}1 & 1.119858 & 2.319812 & -2.004990\end{array}$

$\begin{array}{lllll}1 & -0.683373 & 1.639810 & 0.335225\end{array}$

$\begin{array}{lllll}1 & 5.306491 & 0.466579 & 1.894232\end{array}$

$\begin{array}{lllll}1 & 3.547961 & 0.959722 & 1.679439\end{array}$

$\begin{array}{lllll}1 & 3.982792 & -0.616311 & 2.453904\end{array}$

$\begin{array}{llll}1 & -1.711005 & 2.327487 & -1.607813\end{array}$ 


\section{Characterization Data for MK-6482}

3-(((1S,2S,3R)-2,3-difluoro-1-hydroxy-7-(methylsulfonyl)-2,3-dihydro-1H-inden-4-yl)oxy)-5fluorobenzonitrile (MK-6482):

${ }^{1} \mathrm{H}$ NMR (599 MHz, acetonitrile- $\left.d_{3}\right) \delta 8.06(\mathrm{dd}, J=8.7,2.0 \mathrm{~Hz}, 1 \mathrm{H}), 7.44(\mathrm{ddd}, J=8.2,2.3,1.2 \mathrm{~Hz}, 1 \mathrm{H}), 7.38$ $-7.34(\mathrm{~m}, 1 \mathrm{H}), 7.26(\mathrm{dt}, J=9.6,2.3 \mathrm{~Hz}, 1 \mathrm{H}), 7.15(\mathrm{~d}, J=8.7 \mathrm{~Hz}, 1 \mathrm{H}), 5.96(\mathrm{dd}, J=56.1,4.7 \mathrm{~Hz}, 1 \mathrm{H}), 5.73-$ $5.68(\mathrm{~m}, 1 \mathrm{H}), 5.13(\mathrm{ddt}, J=47.4,17.3,5.0 \mathrm{~Hz}, 1 \mathrm{H}), 3.95(\mathrm{~d}, J=5.8 \mathrm{~Hz}, 1 \mathrm{H}), 3.25(\mathrm{~s}, 3 \mathrm{H})$.

${ }^{13} \mathrm{C}$ NMR (151 MHz, acetonitrile- $\left.d_{3}\right) \delta 164.0(\mathrm{~d}, J=249.3 \mathrm{~Hz}), 158.9(\mathrm{t}, J=1.2 \mathrm{~Hz}), 157.9(\mathrm{~d}, J=11.5 \mathrm{~Hz})$, $145.2(\mathrm{t}, J=4.8 \mathrm{~Hz}), 135.8(\mathrm{~d}, J=3.2 \mathrm{~Hz}), 134.7(\mathrm{dd}, J=2.4,1.4 \mathrm{~Hz}), 130.0$ (dd, J = 16.7, $4.5 \mathrm{~Hz}), 120.7$ (d, J $=3.6 \mathrm{~Hz}$ ), 119.9 (d, J = 2.5 Hz), $117.7(\mathrm{~d}, J=3.7 \mathrm{~Hz}), 117.0$ (d, J=25.4 Hz), 115.6 (d, J = $11.9 \mathrm{~Hz}), 113.7$ (d, $J$ $=24.8 \mathrm{~Hz}$ ), $89.7(\mathrm{dd}, J=200.7,16.4 \mathrm{~Hz}), 87.7(\mathrm{dd}, J=187.0,16.7 \mathrm{~Hz}), 71.0(\mathrm{~d}, J=18.4 \mathrm{~Hz}), 45.7$.

${ }^{19} \mathrm{~F}$ NMR $\left(564 \mathrm{MHz}\right.$, acetonitrile- $\left.d_{3}\right) \delta-109.7,-184.7(\mathrm{~d}, J=7.2 \mathrm{~Hz}),-214.3(\mathrm{~d}, J=7.2 \mathrm{~Hz})$.

HRMS (ESI-TOF) m/z: [M - H] calcd for $\mathrm{C}_{17} \mathrm{H}_{11} \mathrm{~F}_{3} \mathrm{NO}_{4} \mathrm{~S} 382.0361$; found 382.0361.

${ }^{1} \mathrm{H}$ spectrum of MK-6482 (599 MHz, acetonitrile- $d_{3}$ )
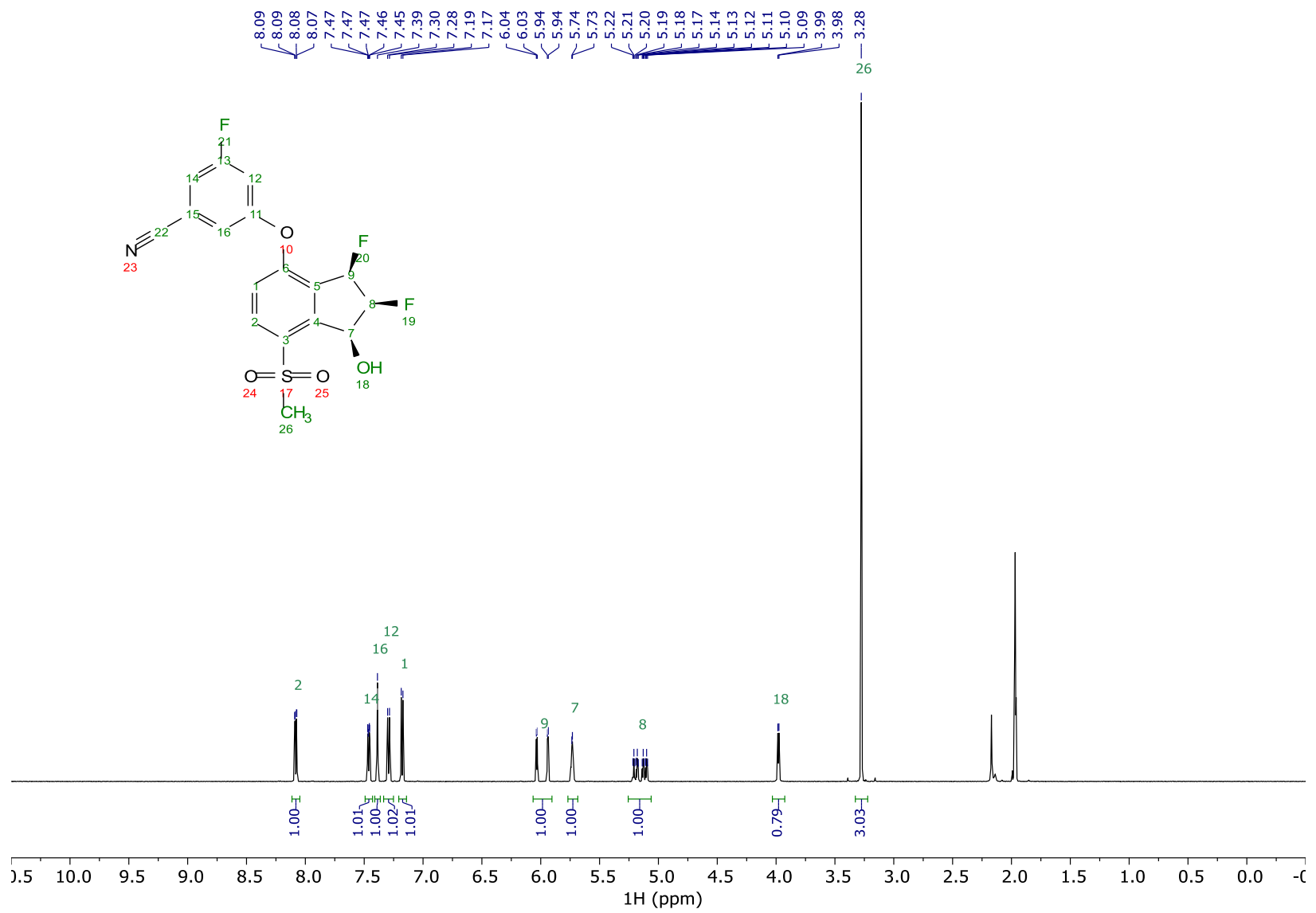
${ }^{13} \mathrm{C}\left\{{ }^{1} \mathrm{H}\right\}$ spectrum of MK-6482 (151 MHz, acetonitrile- $\left.d_{3}\right)$
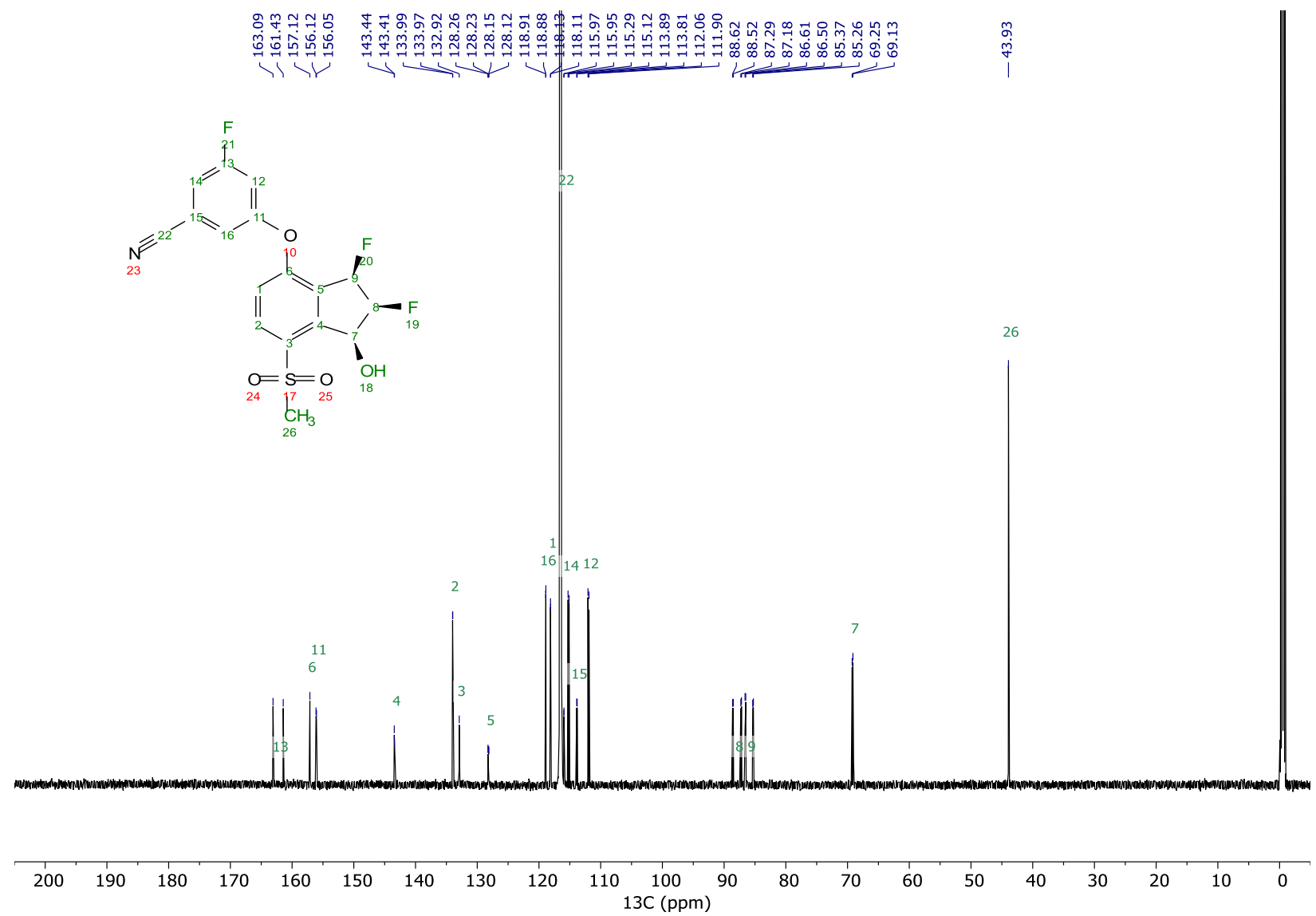
${ }^{19} \mathrm{~F}\left\{{ }^{1} \mathrm{H}\right\}$ spectrum of MK-6482 (564 MHz, acetonitrile- $\left.d_{3}\right)$

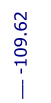

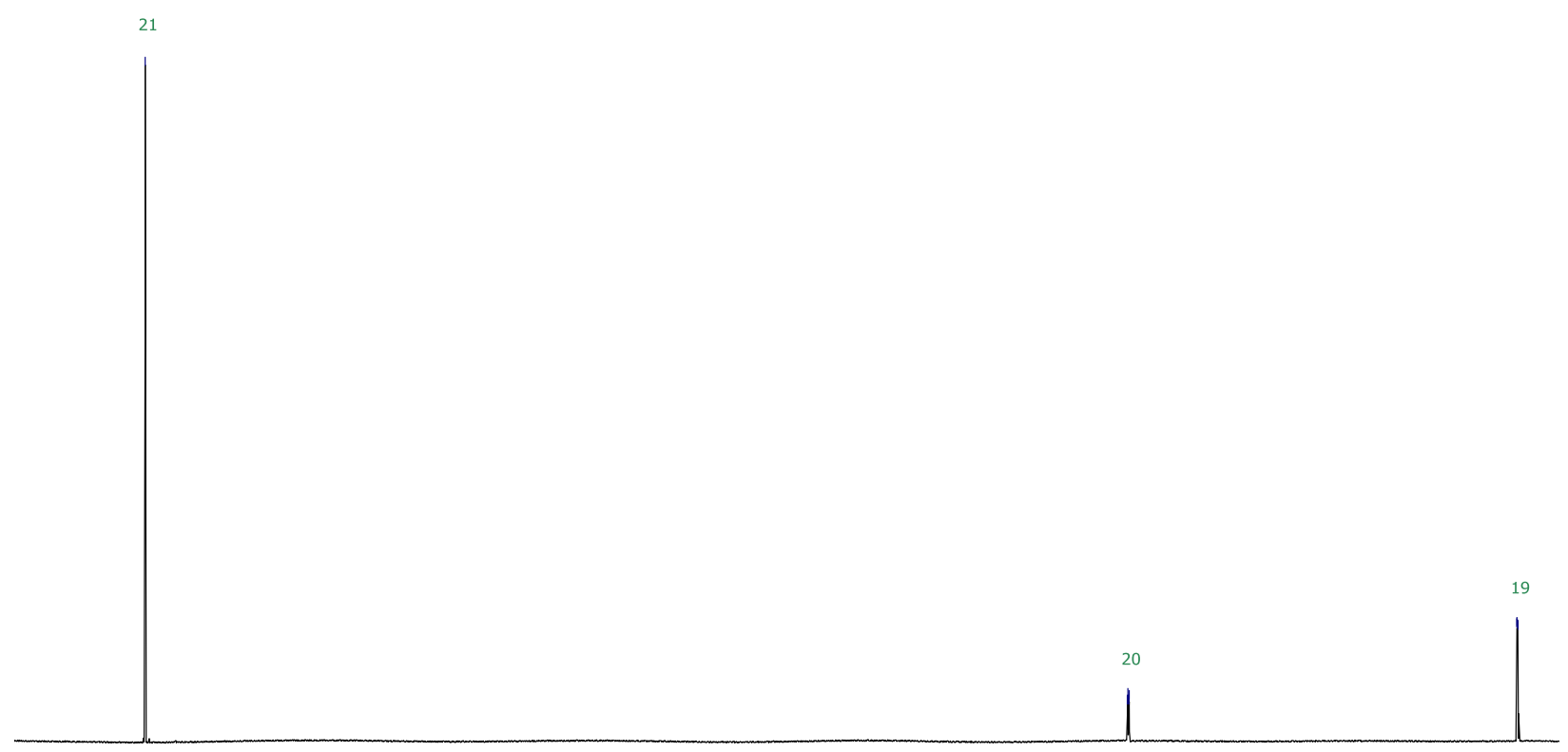

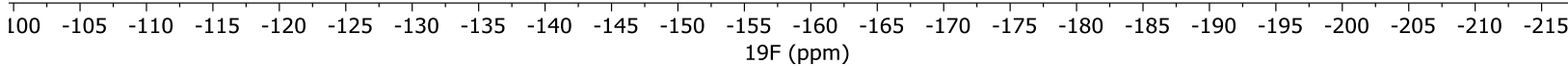

\section{References}

1. Fulmer, G. R.; Miller, A. J. M.; Sherden, N. H.; Gottlieb, H. E.; Nudelman, A.; Stoltz, B. M.; Bercaw, J. E.; Goldberg, K. I. Organometallics. 2010, 29, 2176-2179.

2. Frisch, M. J.; Trucks, G. W.; Schlegel, H. B.; Scuseria, G. E.; Robb, M. A.; Cheeseman, J. R.; Scalmani, G.; Barone, V.; Petersson, G. A.; Nakatsuji, H.; et al. Gaussian 16, Rev. A.03. Gaussian, Inc.: Wallingford, CT, 2016.

3. Zhao, Y.; Truhlar, D. G. The M06 Suite of Density Functionals for Main Group Thermochemistry, Thermochemical Kinetics, Noncovalent Interactions, Excited States, and Transition Elements: Two New Functionals and Systematic Testing of Four M06-Class Functionals and 12 Other Functionals. Theor. Chem. Acc. 2008, 120 (1-3), 215-241. https://doi.org/10.1007/s00214-007-0310-x.

4. Ribeiro, R. F.; Marenich, A. V.; Cramer, C. J.; Truhlar, D. G. Use of Solution-Phase Vibrational Frequencies in Continuum Models for the Free Energy of Solvation. J. Phys. Chem. B 2011, 115 (49), 14556-14562. https://doi.org/10.1021/jp205508z. 